\title{
Experimental Investigation of the Effect of Brake Disconnished by Hvof Method
}

\author{
Mustafa Babagiray $^{1 *}$, Hüseyin Bayrakçeken ${ }^{1}$, Mehmet Çakmakkaya ${ }^{1}$, Faruk Emre Aysal ${ }^{1}$, Salih Karanfil $^{1}$
}

0000-0002-2482-6662, 0000-0002-1572-4859, 0000-0002-9031-3830, 0000-0002-9514-1425, 0000-0001-5401-0341

${ }^{1}$ Automotive Engineering Department, Faculty of Technology, Afyon Kocatepe University, Afyon, 03200, Turkey

\begin{abstract}
In this study; brake discs used in vehicles have investigated. The behavior of these discs during braking, wear and braking distance performance of the coated and uncoated surfaces during the braking process were evaluated. The surface of the commercially produced discs was coated with a thickness of $1 \mathrm{~mm}$ using the HVOF (High Velocity Oxy-Fuel) coating method. In the coating process CoNiCrAlY, WC-Co (88/12), NiCrBSi and MoNiCrBSiFe (Mo 25\%) 4 (four) different ceramic powders were used respectively. Wear and brake distance tests of coated and uncoated discs were performed by braking in a total of 20 brakes in 15 seconds on the brake-suspension tester.

After the brake tests, the surface roughness changes of the discs, surface hardness change, mass loss and the abrasion values on the disc surfaces were determined due to the brake force applied to the discs during the experiment. The most wear on the discs was on the CoNiCrAlY ceramic powder coated disc at $0,4 \mathrm{~g}$, while the least wear occurred on the disc coated with $\mathrm{NiCrBSi}$ ceramic powder at $0,2 \mathrm{~g}$.
\end{abstract}

Keywords: Brake Disc, HVOF, Brake Test, Wear, Ceramic Powder

\section{* Corresponding author \\ Mustafa Babagiray \\ mbabagiray@aku.edu.tr}

Adress: Automotive Engineering Department, Faculty of Technology, Afyon Kocatepe University, Afyon, Turkey

Tel:+902722282543

Research Article

Manuscript Received 24.04.2019

Revised 24.09.2019

Accepted 30.09.2019

Doi: 10.30939/ijastech..557701

\section{Introduction}

Since the late 19 th century and early 20th century, motor vehicles have quickly become indispensable elements of daily life. Particularly as a result of the rapid technological advances that took place in the second half of the 20th century and the 21st century, the speed capacity and the ride comfort of the vehicles developed considerably. This situation has led to the development of the work on the safety measures in vehicles. R \& D studies in vehicle security systems include fields of electronics, software, artificial intelligence as well as material science. A significant part of the work on vehicle safety in the material area is made on the improvement of the brake system components[1].
Friction based brake systems convert the kinetic energy of the vehicle into thermal energy by friction. The amount of heat produced varies with the mass and speed of the vehicle. If the amount of heat generated during braking reaches high values, glare, glass or thermal cracks will form on the disc surfaces. At the same time, the amount of oval and tapered abrasion over time is increasing. High temperatures harden the carbon on the surface of the material and cause the surfaces to be glass. $\mathrm{s}$ a result, the friction force decreases and the sound and vibration increases[2].

Nowadays, brake disc production does not require high technology in the casting process and it is more common to be manufactured by cast iron than it is made of cast iron. Besides, ceramic and composite brake discs are produced with the developing technology. Due to the 
fact that these discs are difficult and cost-effective, surface finishing can be used to change the surface properties of the material[3]. There are many studies in the literature to improve the properties of brake discs. These studies focus on the use of different coating methods and coating materials in terms of material. In 2009 study by Demir, the friction performance of Metco $18 \mathrm{C}$ and $\mathrm{Cr} 3 \mathrm{C} 2-\mathrm{NiCr}$ coated discs were investigated. As a result, it is seen that Metco $18 \mathrm{C}$ and $\mathrm{Cr} 3 \mathrm{C} 2-\mathrm{NiCr}$ coated discs can have a positive effect on vehicle safety. In 2001, Stanford and Jain covered a variety of materials on the brake disc by the Metco method. Among the coating materials used, W en 2.4C (Stellite) material has been found to provide the best performance in terms of wear and corrosion. In his study in 2007, Kaya used CrNiBSi $+80 \%$ WC-Cove $\mathrm{Cr} 3 \mathrm{C} 2-\mathrm{NiCr}$ (75/25) powders on the disc using HVOF method and plasma method. As a result, it was seen that HVOF coating method is more suitable for brake discs than plasma[4-21].

In this study, 4 different ceramic powders were coated on the brake disc using the HVOF method. Coated and uncoated brake discs were subjected to friction testing using a brake suspension tester. As a result of the brake tests performed, each brake disc is used to measure the linear force on the vehicle during braking. After the brake tests, the effect of roughness on the surface of the discs, weight loss, surface hardness change, average wear value and braking distance have been obtained.

\section{Materials and Methods}

In the study, four brake disc surfaces were coated with HVOF coating method. An uncoated disc was also used. Disc surfaces; CoNiCrAlY (Disc 1), WC-Co (88/12) (Disc 2), NiCrBSi (Disc 3) and MoNiCrBSiFe (Mo 25\%) (Disc 4) are coated with HVOF coating method using ceramic powder mixtures. HVOF is one of the most widely used methods of thermal spray coating methods. In recent years, thermal spray technology has been continuously developing. The method was developed as an alternative to the D-Gun method in the early 1980s. The coatings obtained with HVOF have very little porosity and have high density due to high spray particle velocities[22]. Commercial brake discs made of cast iron were used in the study. In this study, five brake discs, one original disc and four HVOF coating methods, were subjected to brake performance tests. The manufacturing dimensions of the brake discs used in the study are shown in Figure 1.
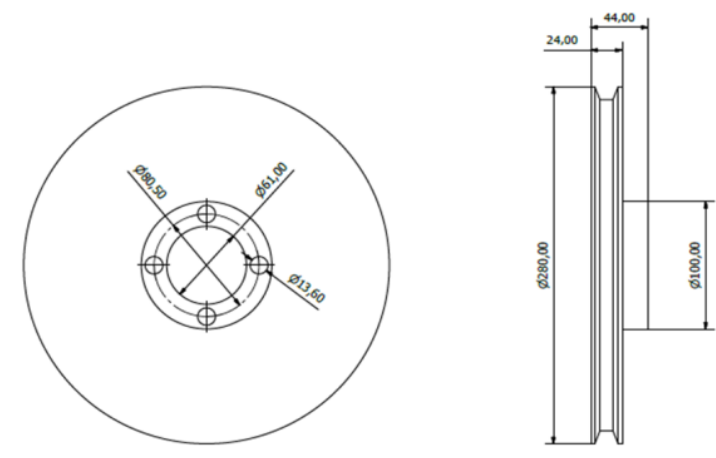

Fig. 1. Technical Picture of Brake Disc Used in Operation

Uncoated and coated discs were subjected to braking performance effectiveness testing. The tests carried out in the test device shown in Figure 2 can be made in two different ways thanks to both the electric motor and the internal combustion engine within the device. Tests also include; It provides the ability to test according to three different road conditions such as pit, mound and flat road conditions. The braking tests were carried out at $750 \mathrm{rpm}$ with a constant speed drive.

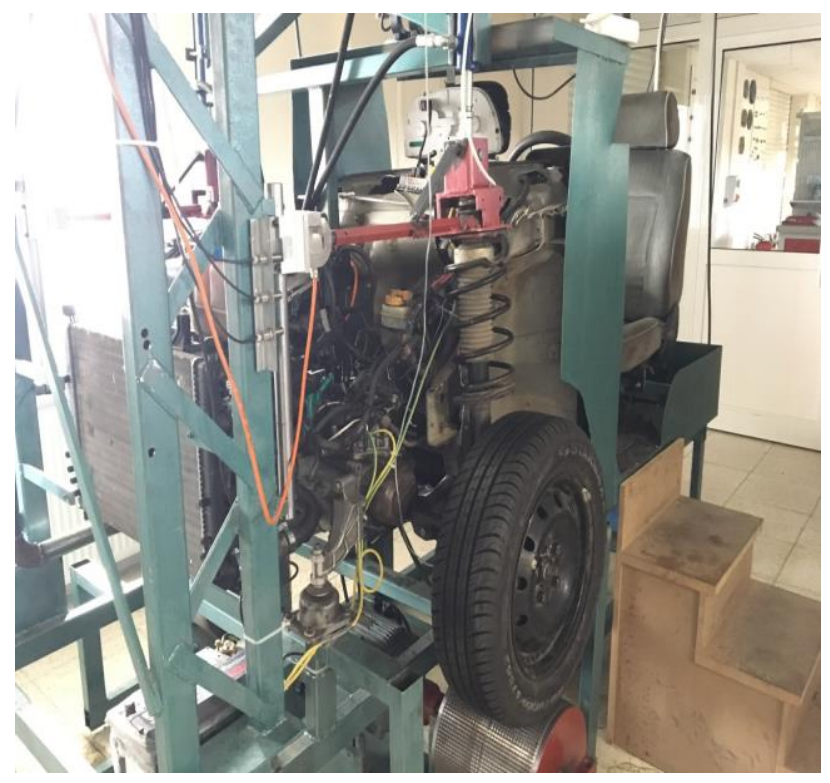

Fig. 2. Brake Suspension Tester

Brake tests were performed at the same rate of braking 20 times every 15 seconds. As a result of the braking tests, the linear force to the suspension block is measured during braking. Therefore, as a result of the experimental study, the effect of different coating materials on the driving comfort during braking was investigated in addition to wear analysis. Following the brake tests, SEM images were analyzed by XRD for the wear 
behavior of the brake discs. Surface roughness change, mass loss and surface hardness change values of the brake discs tested were measured.

\section{Discussion and Conclusion}

The original and coated discs were measured at 5 different points from their surface before and after abrasion. The average of 5 separate roughness values was found. The measurements were measured by surface roughness measurement device which was introduced perpendicular to the slip lines formed during the rotation of the disc. The changes in surface roughness of the discs are given in Figure 3.
In the study, the closest roughness values to the uncoated disc were found on the Disc 4. Other coated discs have lower surface roughness values. Surface roughness values on Disc 1, Disc 3 and Disc 4 are close to each other. This may be due to the same coating method. In addition, all of the powder mixtures have a nickel element. Therefore, the roughness values may be close. The surface roughness value of the Disc 2 is lower than that for other coated discs and uncoated disc. The difference in roughness values can be attributed to the different chemical properties of the powders.

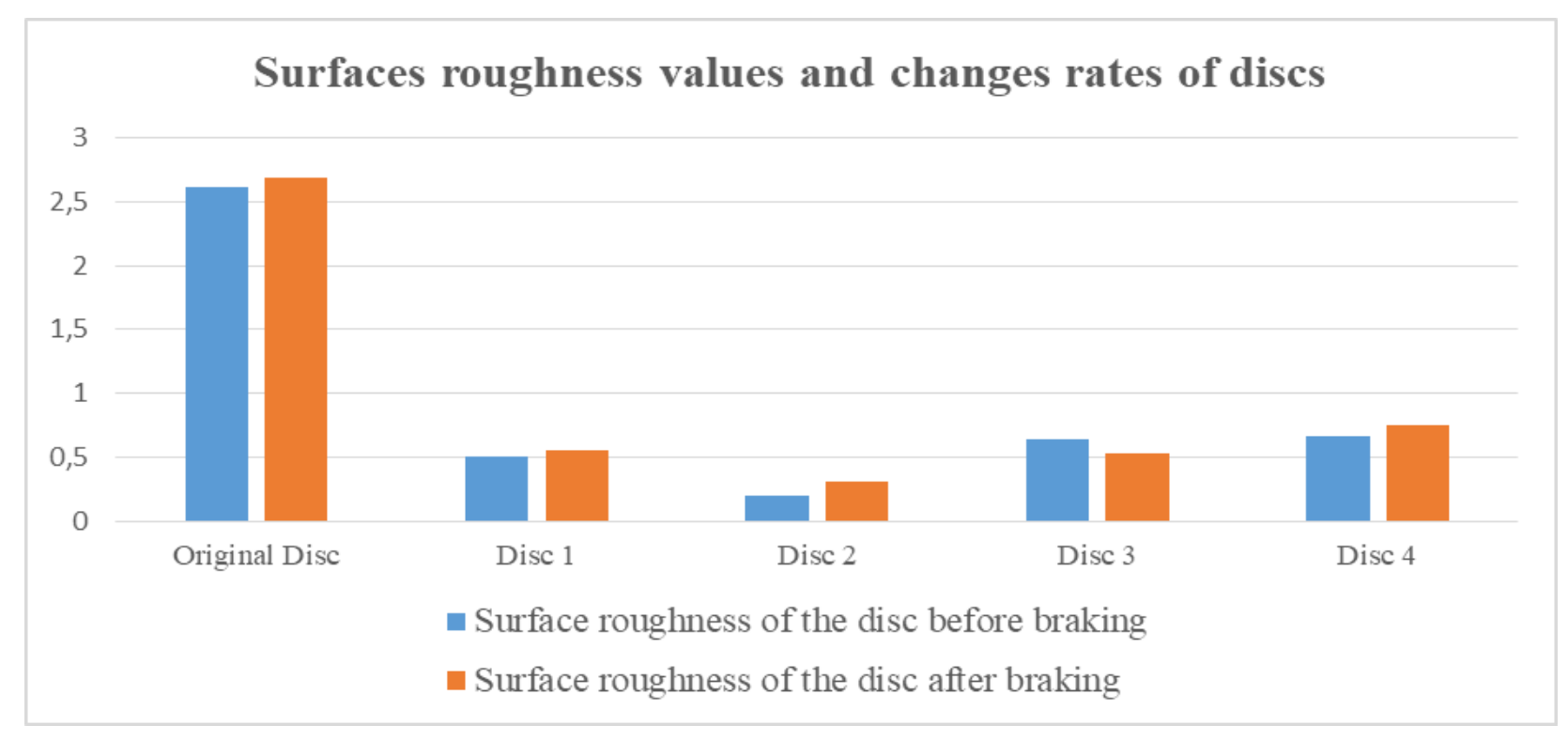

Fig. 3. Surface roughness values and change rates of discs.

Micro hardness was measured in order to examine the surface hardness change after brake tests. 4 different points are taken from each sample surface. The first two values were taken from the non-abrasive surface and the last two values were taken from the surface. The hardness values for each sample were averaged. During the hardness analysis of the samples, the diamond was measured at 1000 gr. constant load. All samples were analyzed at this load. Figure 4 shows the mean values of the samples whose hardness is measured. When the values obtained in the hardness measurement are compared, the microhardness value taken from the non-friction surfaces is seen in the sample Disc 3 ceramic powder with the highest $793.65 \mathrm{HV}$. The minimum micro-hardness value is found in the original disc sample with 169.15 HV. Micro hardness values obtained from the surfaces formed after the friction were determined with 891.15
HV micro hardness and the highest value was found in Disc 3 sample. The lowest micro hardness value was also determined in the original sample with $222.55 \mathrm{HV}$ hardness value. It is observed that the change in hardness observed after the brake tests is the highest in the original disc with $31.57 \%$ increase. The increase in this hardness value leads to metallurgical transformation on the disc surface due to the friction-induced heating increase and rapid cooling on the disc surface during braking. In other words, the heat generated on the disc surface diffuses from the surface of the disc to the center rapidly from the surface of the disc with conventional transmission. The lowest hardness change rate was $2.02 \%$ for Disc 2. The surface hardness of all of the brake discs used increases while the surface hardness of the Disc 1 is reduced by $4.01 \%$ as opposed to other brake discs. The shell coating formed by cermet coatings on the disc sur- 
Also, the hardness values of the Sermet powders used are different and different hardness values are obtained. face creates a heat barrier and hence the hardness changes may be different due to the slower progression of the heat formed on the surface towards the core of the disc.

\section{Micro hardness values of discs}

\section{0}

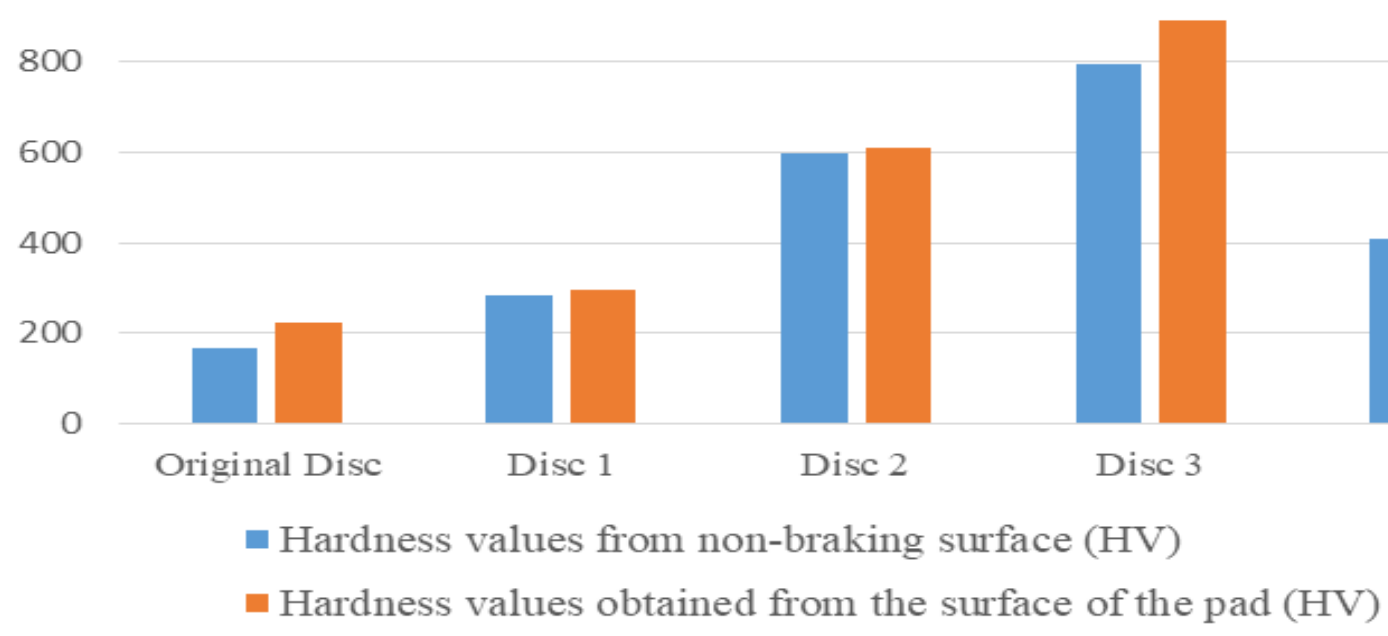

Fig. 4. Micro hardness values of discs

The wear amounts of the uncoated and coated discs used are compared in Table 1 in terms of mass loss.

Table 1. Weight change of discs before and after testing.

\begin{tabular}{c|c|c|c|c}
$\begin{array}{c}\text { Test } \\
\text { Samples }\end{array}$ & $\begin{array}{c}\text { Mass } \\
\text { before } \\
\text { braking } \\
(\mathbf{g})\end{array}$ & $\begin{array}{c}\text { Mass } \\
\text { after } \\
\text { braking } \\
(\mathbf{g})\end{array}$ & $\begin{array}{c}\text { Mass loss } \\
(\mathbf{g})\end{array}$ & $\begin{array}{c}\text { Mass loss } \\
\text { rate (\%) }\end{array}$ \\
\hline $\begin{array}{c}\text { Original } \\
\text { Disc }\end{array}$ & 4254.5 & 4254.2 & 0.3 & 0.007 \\
\hline Disc 1 & 4329.5 & 4329.1 & 0.4 & 0.009 \\
\hline Disc 2 & 4321.2 & 4320.9 & 0.3 & 0.007 \\
\hline Disc 3 & 4355.8 & 4355.6 & 0.2 & 0.005 \\
\hline Disc 4 & 4299.3 & 4299.0 & 0.3 & 0.007
\end{tabular}

The minimum mass loss after disc was calculated on the Disc 3 powder mixture with $0.2 \mathrm{~g}$. The maximum mass loss was calculated on Disc 1 with $0.4 \mathrm{~g}$. Uncoated disc, Disc 2 and Disc 4 with an equal amount of mass loss of $0.3 \mathrm{~g}$ mass was calculated. The average of the forces on the suspension block during braking tests is given in Table 2 for each brake disc. The highest force was observed on Disc 4, while the lowest strength was observed on the Disc 3. As a result, it is seen that the ride comfort during braking will be provided when using the Disc 3.

\section{Results}

In this study, 4 different materials were coated on the brake disc using HVOF coating method. The coated brake discs and the uncoated brake disc were subjected to friction testing using a brake suspension tester. The brake tests were performed by pressing the brake 20 times evenly every 15 seconds. As a result of the tests, it was found that the brake disc which had the least damage to the comfort of the vehicle during braking was the Disc 3. However, as a result of the measurements made, the disc with the highest surface hardness and the least mass loss is seen as the Disc 3. This shows that Diks 3 is more suitable than the others in terms of surface hardness, vehicle comfort and mass loss. However, the surface roughness of all other discs increased after the tests, while the surface roughness of the Disc 3 decreased. The gradual reduction of the surface roughness will cause the glass to become discolored on the brake disc and the friction coefficient will fall below the critical level. Therefore, considering the other parameters, it is seen that Disc 3 is usable but it is seen that it is not suitable for use when the surface roughness change is taken into 
Ph.D Thesis.

[9] Erdem, M., Altıparmak, D. (2014). Fren Disk Sicaklığının Frenleme Performansına Etkisi. Gazi Üniv. Müh. Mim. Fak. Der. Cilt 29, No 2, 425-432.

[10]Ericksson, M., Bergman, F. Jacobson, S. (2002). On the nature of tribological contact in automotive brakes, Wear, 252: 26-36

[11]Filip P. Weiss, Z. D. Rafaja, D. (2002). On friction layer formation in polymer matrix composite materials for brake applications. Wear, 252: 189-198.

[12]Güney, B., Mutlu, I. Dry friction behavior of NiCrBSi$\% 35 \mathrm{~W} 2 \mathrm{C}$ coated brake disks. Material pruefung/Materials Testing. 59(5):497-505, 2017.

[13]Kao, T.K. Richmond, J.W. Douarre, A. (2000). Brake disc hot spotting and thermal judder: an experimental and finite element study, International Journal of Vehicle Design, 23, 3-4, 276-296.

[14]Kaya, A. Ö. (2007). Plazma Püskürtme Ve Hvof Yöntemleri Kullanılarak Cr3c2nicr(75/25) ve Crnibsi+\%80 Wc-Co Tozlarıyla Kaplanan Çeliğin Yapısı Ve Yüzey Özellikleri. Gebze Technical University, Institute of Natural and Applied Science, Master Thesis.

[15]Lee, K. Barber, J.R. (1994). An experimental investigation of frictionally excited thermoelastic instability in automotive disk brake sunder a drag brake application, Journal of Tribology.116, 3, 409-414.

\section{References}

[1] Bayrakçeken, H. (2002). Motorlu taşıtlarda fren performans analizi ve geliştirilen test cihazında uygulanması. Gazi University Institute of Natural and Applied Science, PhD Thesis.

[2] Düzgün, M., Yıldız, Y. (2009). Soğutma Kanallı Fren Disklerinin Frenleme Kuvvetlerine ve Isı Değişimine Etkileri. International Advanced Technology Symposium, Karabük, Turkey.

[3] Ulutan, M. (2007). AISI 4140 Çeliğinin Yüzey Sertleştirme İşlemleri Ve Kaplama Yöntemleri Sonrası Mekanik Davranışlarının Araştırılması. Eskisehir Osmangazi University, Institute of Natural and Applied Science, PhD. Thesis.

[4] Deamaley, I.(1985). Adhesive, abrasive and oxidative wear in ion-implanted metals. MaterialsScience-Engineering, 69:139147

[5] Seong, K.R. Michael, G.J. ve Peter, H.S.T. "The role of friction film in friction, wear, andnoise of automotivebrakes", ABS Traction Control andBrake Components, SAE: 900004 , 1990.

[6] Anderson, A.E. (1992). Friction and wear of automotive brakes, in: ASM Handbook: Friction, Lubrication and Wear Technology, ASM International, Materials Park, OH, 18:569577.

[7] Bergmann, F., Eriksson, M., Jacobson, S. (1999). A software based measurement system or test and analysis of automotive brake squeal. Tribo Test Journal. 5(3):265-275.

[8] Demir, A. (2009). Fren Disklerine Uygulanan Kaplamaların Frenleme Performansina Etkisinin Deneysel İncelenmesi. Kocaeli University, Institute of Natural and Applied Science,
[16]Mutlu, İ. (2002) Seramik Katk1lı Asbestsiz Otomotiv Fren Balatası Üretimi ve Frenleme Karakteristiğinin Deneysel İncelenmesi. Sakarya University Institute of Natural and Applied Science, Ph.D Thesis.

[17]Shorowordi, K.M.,Haseeb, A.S.M.A., Celis, J.P. (2004). Velocity effects on the wear, friction and tribochemistry of aluminium MMC sliding against phenolic brake pad, Wear, 256: 1176-1181.

[18]Stanford, M.K. and Jain, V.K. (2001). Friction and wear characteristics of hard coatings. Wear, 250/51, 990-996

[19]Stokes, J. (2003). Production of coated and free-standing engineering componenets usingt he HVOF process. Dublin City University, Ph.D Thesis.

[20]Thuresson, D. (2004). Influence of materialproperties on slidingcontactbrakingapplications. Wear. 257, 451-460.

[21]Toros, M. (2011). Fren Balatalarında Nano Malzemelerin Kullanımının Frenleme Performansına Etkilerinin Deneysel Araştırılması. Selcuk University Institute of Natural and Applied Science, Master Thesis.

[22] Karanfil, S. (2017). Fren disklerinin HVOF Yöntemi ile kaplanması ve taşıtlarda fren performansına etkisinin araştırılması. Afyon Kocatepe University, Master Thesis. 